\title{
BENCANA DAN PERUBAHAN IDENTITAS DESA BULAK 1971-2000an
}

\author{
Muhammad Alfan Jazli dan Emy Wuryani \\ e-mail: 152016005@student.uksw.edu
}

Program Studi Pendidikan Sejarah-Fakultas Keguruan dan Ilmu Pendidikan, Universitas Kristen Satya Wacana, Salatiga, Indonesia

\begin{abstract}
This article discusses the history of the disaster that struck the Bulak Village in the area of Jepara, Central Java, Indonesia in the 1971-2000s period. Disasters that continue to occur in the village of Bulak force villagers to move to the new village location. The new village was named after Desa Bulak Baru as a sign that the name of Desa Bulak Baru was not part of the expansion of the old village, but as a collective memory of the name of their previous village. To see that change, the writer sees it in the lens of migration in the local definition, namely village bedol. Bedol Desa is a term for the people of the villages in Java who migrate. The study of village bedol events in the perspective of social history studies. In 1981 a village bedol event occurred in Bulak Village, Jepara Regency. The destination of the bedol desa is the location Desa Bulak Baru. Naming that includes a change of identity, but does not eliminate the old name as the historical basis of a Bulak Village. The method used in this study is the historical method, which includes: (1) heuristics or source tracking, (2) source criticism to verify the information obtained, (3) analysis, and (4) historiography or historical writing.
\end{abstract}

Keywords: Disasters, change identitiy of village, bedol desa 


\section{PENDAHULUAN}

Sebagian dari persoalan masyarakat adalah bencana. Bencana dalam banyak hal selalu mempengaruhi kehidupan masyarakat. Pengaruh itu dapat dirasakan oleh individu atau suatu kelompok masyarakat. Sumber masalah yang terdapat dalam masyarakat ada yang berasal dari dalam dan dari luar luar. Dari luar masyarakat, dapat disebabkan oleh peristiwa bencana alam, kerusakan lingkungan, atau karena kebijakan pemerintah seperti pemindahan penduduk melalui transmigrasi atau suatu pemukiman terdampak proyek pertambangan atau pembuatan bendungan. Dari dalam biasanya karena keinginan dari dalam warga masyarakat yang ingin pindah.

Sebagai gambaran, bencana tersebut di atas terjadi pada salah satu desa di Jawa Tengah, yakni masyarakat Desa Bulak, wilayah Jepara. Masalah yang terjadi pada tahun 1979 adalah bencana alam di mana sering terjadi Banjir Rob atau banjir air laut ketika air laut dalam keadaan pasang di desa Bulak. Kondisi itu terus terjadi hingga membuat pemerintah Jawa Tengah melakukan intervensi memindahkan penduduk Desa Bulak melalui transmigrasi. Bantuan program transmigrasi ditawarkan Pemerintah Kabupaten Jepara kepada masyarakat Desa Bulak supaya mereka mendapatkan tempat tinggal yang baru. Tawaran program transmigrasi dari pemerintah tersebut ditolak oleh masyarakat. Masyarakat direlokasi ke tempat baru dalam satu lingkup daerah dari hasil kesepakatan antara pemerintah Kabupaten Jepara dengan pemerintah Desa Bulak.

Perpindahan yang dilakukan masyarakat tersebut kemudian membentuk desa baru dengan nama Desa Bulak Baru. Walaupun masyarakat melakukan perpindahan tetapi sistem dan struktur pejabat pemerintahannya tidak berubah seperti saat sebelum pindah. Perpindahan dengan cara tersebut dinamakan dengan bedol desa. Pasca bedol desa, masyarakat mengalami perubahan dalam hal pekerjaan serta fasilitas umum desa. Berdasarkan latar belakang tersebut maka penelitian ini bertujuan untuk: (1) Menjelaskan penyebab masyarakat Desa Bulak pindah dan membentuk Desa Bulak Baru, (2) Menjelaskan proses perpindahan masyarakat Desa Bulak ke Desa Bulak Baru, dan (3) Menjelaskan kondisi kehidupan masyarakat setelah menempati Desa Bulak Baru.

\section{KAJIAN PUSTAKA}

\section{Definisi: Masyarakat, Desa, dan Bedol Desa}

Menurut Hartono dalam (Herabudin, 2015: 73-74) istilah masyarakat berasal dari bahasa Arab musyarak yang berarti berkumpul bersama, hidup bersama dengan saling berhubungan dan saling mempengaruhi. Masyarakat merupakan sekelompok manusia yang hidup bersama dengan saling berhubungan dan berinteraksi antar individu. Ciri-ciri umum masyarakat antara lain: hidup bersama dan bergaul dengan kurun waktu yang cukup lama, sebuah sistem hidup bersama, dan individu-individu dalam masyarakat sadar bahwa dirinya merupakan satu kesatuan.

Masyarakat pedesaan merupakan sekelompok manusia yang hidup bersama dalam suatu wilayah dengan saling berhubungan dan berinteraksi untuk memenuhi kepentingan hidup mereka. Hubungan dan interaksi tersebut lebih besar dilakukan dengan anggota kelompoknya sendiri dibandingkan dengan kelompok lain yang 
berada di luar wilayahnya (Soekanto, 1982: 146).

Desa berasal dari kata swadesi (bahasa Sansekerta) merupakan suatu kesatuan masyarakat hukum dalam suatu wilayah yang berwenang untuk mengatur dan memenuhi kebutuhannya berdasarkan asal usul atau adat istiadat yang harus diakui dan dihomati dalam pemerintahan Negara Kesatuan Republik Indonesia (NKRI) (Syafrudin dan Na'a, 2010: 2). Secara umum desa dicirikan dengan pertanian seperti ungkapan Egoen E. Bergel (Rahardjo, 2014: 29) yang mendefinisikan desa sebagai pemukiman para petani. Desa tidak harus dicirikan dengan pertanian tetapi daerah yang digunakan sebagai tempat tinggal kelompok masyarakat yang relatif kecil dan juga untuk memenuhi kebutuhan hidup mereka.

Dalam skripsi yang ditulis Noviarti dengan judul Dinamika Sosial Kehidupan Transmigrasi di Nagari Kamang Kabupaten Sijunjung 1993-2014 (2016: 15) bedol desa (berkaitan dengan transmigrasi) merupakan pemindahan penduduk terhadap suatu desa beserta sistem pemerintahannya yang dilakukan secara masal ke tempat yang baru dan biasanya perpindahan tersebut disebabkan oleh bencana alam. Sedangkan menurut Kamus Besar Bahasa Indonesia (2008: 156) bedol desa adalah suatu pemindahan penghuni desa ke tempat lain, biasanya berhubungan dengan proses transmigrasi.

\section{METODE PENELITIAN}

Metode penelitian yang digunakan adalah metode sejarah yang melalui melalui 4 tahapan, yakni: (1) Heuristik yaitu mencari dan mengumpulkan sumber sejarah dari buku, dokumen, pengamatan objek penelitian, dan keterangan pelaku atau orang yang mengetahui peristiwa bedol desa. Minimnya sumber tertulis dan tokoh yang mengetahui peristiwa membuat keterbatasan sumber yang dimiliki peneliti (2) Kritik Sumber yaitu menyeleksi sumber dengan melihat material dan tanggal dari sumber tertulis apakah sezaman atau tidak, melihat usia narasumber di atas 50 tahun (tidak terpaut jauh dengan peristiwa bedol desa) dan statusnya sebagai masyarakat desa bulak sebelum bedol desa tahun 1982. Selain itu kritik sumber dilakukan juga dengan cross check data dengan data lainnya yang diperoleh. (3) Interpretasi merupakan penafsiran bukti-bukti sejarah yang diperoleh dengan cara menghubungkan fakta-fakta yang ada yang kemudian dibuat kesimpulan tentang bedol Desa Bulak tahun 1982. (4) Historigrafi yaitu penulisan sejarah perpindahan masyarakat dan lokasi Desa Bulak tahun 1981 ke Desa Bulak Baru. Alasan mengapa masyarakat Desa Bulak direlokasi ke wilayah Desa Bulak Baru dan kondisi kehidupan masyarakat setelah pindah ke Desa Bulak Baru dijelaskan tersendiri.

\section{HASIL PENELITIAN DAN PEMBAHASAN}

\section{Desa Bulak dan Perubahan Identitasnya ke Desa Bulak Baru}

Kata Bulak berasal dari Bugel pinggir lak yang berarti daerah sekitar Bugel yang dekat dengan muara sungai dan terletak di Laut Jawa. Kata pinggir dalam Bahasa Indonesia mengarah pada sisi samping atau sebelah dan kata lak merupakan sebuah sebutan dari masyarakat sekitar untuk muara atau ujung sungai yang mengalir ke laut. 
Desa Bulak terletak di sebelah barat Desa Bugel yang telah berdiri lebih awal. Wilayah Desa Bulak berada di wilayah Kecamatan Kedung, Kabupaten Jepara Pripinsi Jawa Tengah. Sebelum menjadi sebuah desa, Bulak merupakan daerah pesisir pantai yang digunakan masyarakat sekitar untuk mencari ikan. Bulak merupakan daerah yang banyak hasil lautnya seperti ikan teri, udang, dan rebon. Karena melimpah hasil lautnya menjadikan para nelayan yang berasal dari desa sekitarnya seperti Desa Bugel, Jondang, Menganti, Semat, dan Tanggul Tlare tertarik untuk datang bekerja di Bulak. Daerah Bulak kemudian digunakan para nelayan untuk istirahat setelah bekerja. Para nelayan juga menjadikan Bulak sebagai tempat untuk menepi dan menyandarkan perahu mereka. Ramainya daerah Bulak dengan aktivitas para nelayan tidak terlepas dari kekayaan hasil lautnya yang banyak di terdapat di laut dangkalnya.

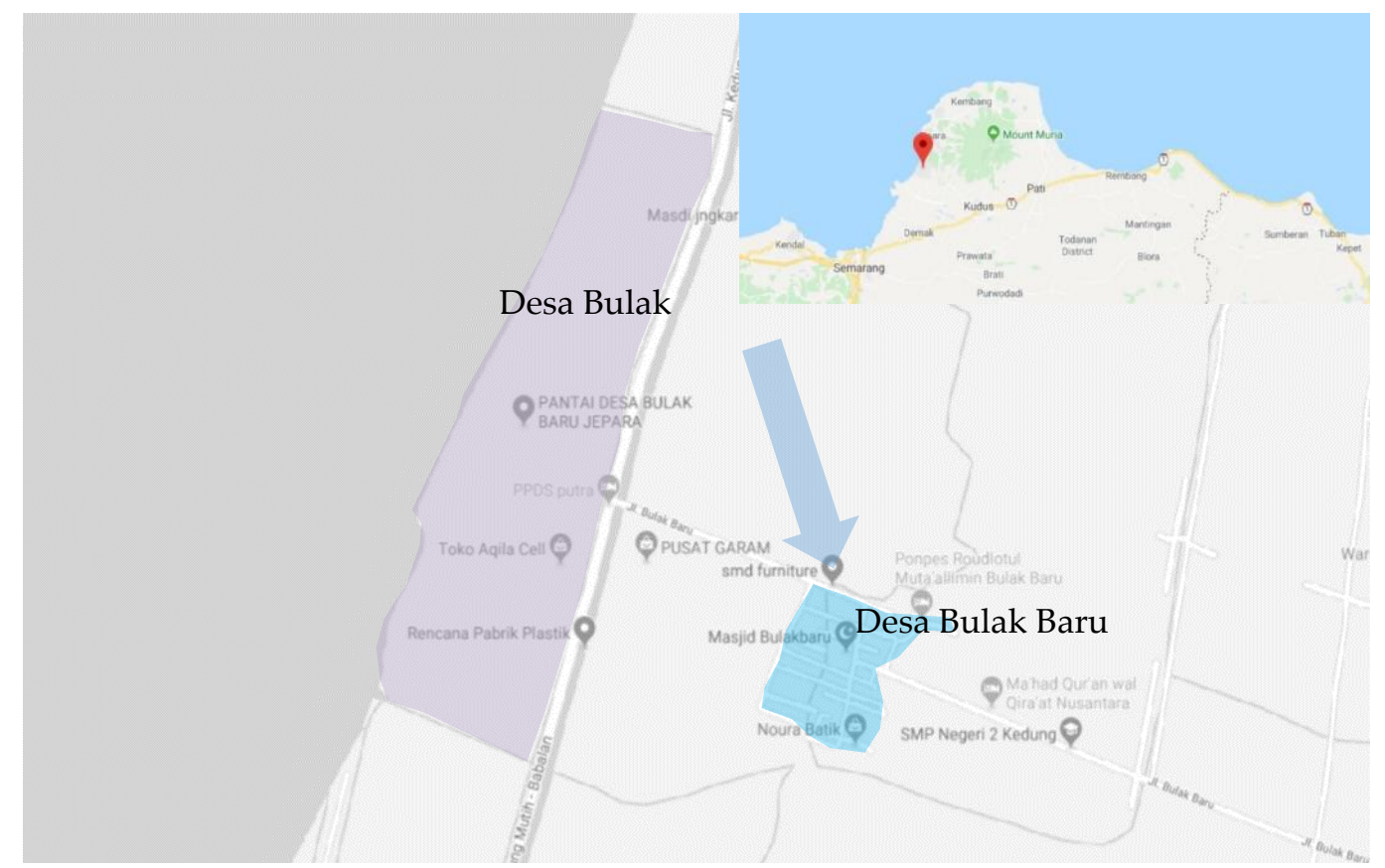

Gambar 1; Desa Bulak dan Bulak Baru.

Sumber: diolah dari google.com/map

Menurut sumber lisan yang dituturkan oleh Sedyo Sedimin, orang-orang yang datang ke Bulak jauh sebelum dia datang, adalah karena hasil lautnya yang melimpah. Pak Sedyo Sedimin berasal dari Demak dan merantau ke Bulak. Sedyo Sedimin datang ke Bulak untuk bekerja sebagai nelayan karena mendengar kabar bahwa di daerah Bulak kaya dengan hasil lautnya. Sedyo Sedimin dipercaya bahwa masyarakat leluhur Bulak yang mengawali membuat pemukiman dan mendirikan Desa Bulak yang dia huni. Rumah Sedyo Sedimin mendirikan sebuah gubug (rumah kecil) di pesisir pantai Bulak. Rumah itu digunakan sebagai tempat tinggal menetap.

Para nelayan yang lain kemudian meniru langkah Sedyo Sedimin dalam mendirikan gubung sebagai tempat istirahat karena jarak antara daerah Bulak dengan desa asal para nelayan cukup jauh sekitar $5 \mathrm{Km}$ sampai $8 \mathrm{Km}$. Tetapi para nelayan tersebut tidak menetap di Bulak dan hanya tinggal di gubug untuk beberapa hari saja sebelum pulang ke desa asalnya. Baru beberapa saat kemudian ada sekitar 10 orang nelayan yang mengikuti langkah Sedyo Sedimin untuk tinggal menetap di Bulak. Bahkan mereka turut serta memboyong keluarga untuk tinggal di Bulak. Hal 
itu dilakukan agar lebih efisien tanpa harus pulang pergi dan mereka merasa kebutuhan sandang pangannya sudah terpenuhi dari hasil bekerja di Bulak, sehingga mereka berani memutuskan tinggal menetap di Bulak. Melihat hal tersebut kemudian banyak nelayan yang kemudian ikut memboyong keluarganya dan menetap di Bulak. Berdasarkan hal itu, maka pemukiman baru tersebut kemudian dinamakan Bulak yang berarti Bugel pinggir lak.

\section{MASYARAKAT BULAK DI DESA BULAK BARU}

Desa Bulak terletak di pesisir pantai Laut Jawa tepatnya di sebelah barat Desa Bulak Baru Kecamatan Kedung Kabupaten Jepara berjarak sekitar $3 \mathrm{Km}$ ke arah barat (lihat gambar 1). Luas wilayah Desa Bulak seluas 185 Ha dengan kondisi tanah yang berlumpur. Desa Bulak juga mempunyai hutan mangrove yang berada di pesisir pantai. Kondisi kehidupan masyarakat Desa Bulak sebelum bencana mempunyai kehidupan yang mapan. Jumlah penduduk Desa Bulak pada tahun 1979-1982 berjumlah 150 keluarga. Mayoritas masyarakat Desa Bulak tidak mengenyam pendidikan formal. Masyarakat pada umumnya mendapatkan pendidikan agama dari para kyai atau tokoh agama. Pendidikan agama tersebut biasanya dilakukan di masjid atau pondok (musholla). Pendidikan formal baru didapatkan masyarakat pasca kemerdekaan Republik Indonesia dan baru sebatas pendidikan sekolah dasar. Masyarakat yang mau belajar di pendidikan formal harus pergi ke desa sekitar. Hal itu disebabkan karena di Desa Bulak tidak mempunyai lembaga pendidikan/sekolah.

Di Bulak, hanya sebagian masyarakat yang melanjutkan ke jenjang sekolah menengah. Mayoritas masyarakat Desa Bulak hanya tamatan sekolah dasar dan setelah lulus mereka memilih untuk bekerja dan membantu keluarga. Mata pencaharian masyarakat Desa Bulak sebagian besar adalah nelayan. Ada pula masyarakat yang bekerja sebagai petani, peternak, dan bekerja di tambak. Masyarakat yang menjadi petani adalah orang-orang yang mempunyai lahan persawahan. Lahan persawahan tersebut jika tidak digarap sendiri biasanya disewakan atau dikerjakan kepada buruh tani. Hewan ternak yang dipelihara masyarakat Desa Bulak kebanyakan adalah kerbau. Untuk masyarakat yang bekerja di tambak, biasanya di tambak garam dan tambak ikan. Para pekerja itu ada yang ditambak sendiri dan juga di tambak orang lain (buruh). Dalam bidang pemerintahan Desa Bulak pemimpin desa ditunjuk oleh rakyat dan dijabat secara turun-temurun dengan masa jabatan yang panjang. ${ }^{1}$ Baru setelah kemerdekaan Republik Indonesia muncul sistem pemerintah Rukun Tetangga (RT) dan Rukun Warga (RW) yang merupakan produk bekas peninggalan pemerintah pendudukan Jepang.

Desa Bulak Baru merupakan wilayah administratif Kecamatan Kedung Kabupaten Jepara, Provinsi Jawa Tengah. Luas Desa Bulak Baru 87 ha. Wilayah yang digunakan untuk pemukiman diperkirakan mencapai 7 ha. Letak geografis wilayah Desa Bulak Baru berada di area persawahan (lihat gambar 1). Desa Bulak Baru wilayahnya terdiri dari 1 RW dan 4 RT. Untuk batas wilayah Desa Bulak Baru adalah sperti berikut ini. Di sebelah utara berbatasan dengan Desa Tanggul Tlare, di sebelah timur berbatasan dengan Desa Bugel, di sebelah selatan berbatasan dengan Desa

\footnotetext{
${ }^{1}$ Kondisi itu terjadi sebelum diberlakukan peraturan baru saat ini yang dipilih langsung.
} 
Panggung, dan di sebelah barat berbatasan langsung dengan Laut Jawa. Dalam hal kependudukan, Desa Bulak Baru pada tahun 1983-2000 mempunyai jumlah penduduk seperti berikut ini:

Tabel 1. Jumlah penduduk Desa Bulak Baru tahun 1983-2000

\begin{tabular}{|l|l|l|l|}
\hline \multirow{2}{*}{ Tahun } & \multicolumn{2}{|l|}{ Penduduk } \\
\cline { 2 - 4 } & Laki-laki & Perempuan & Jumlah \\
\hline $\mathbf{1 9 8 3 - 1 9 8 9}$ & 329 & 319 & 648 \\
\hline $\mathbf{1 9 9 0 - 1 9 9 6}$ & 358 & 378 & 736 \\
\hline $\mathbf{1 9 9 7 - 2 0 0 0}$ & 376 & 395 & 771 \\
\hline
\end{tabular}

Sumber: Rekap Data Kependudukan Desa Bulak Baru (tanpa tahun)

Data tabel di atas memperlihatkan bahwa pada tahun 1983- 2000, Desa Bulak Baru selalu mengalami peningkatan jumlah penduduk. Peningkatan pertumbuhan penduduk Desa Bulak rata-rata sebesar $2 \%$ per tahun. Jika digolongkan berdasarkan jenis kelamin, maka jumlah penduduk antara laki-laki dan perempuan jumlahnya tidak jauh berbeda pada periode 1983-1989, dengan komposisi jumlah laki-laki lebih banyak. Namun pada periode 1990-1996 dan 1997-2000 jumlah perempuan lebih banyak dibanding dengan penduduk laki-laki. Persentase rata-rata jumlah pertumbuhan perempuan pertahun mencapai $4.47 \%$, sedangkan persentase rata-rata pertumbuhan laki-laki sebesar $2.76 \%$ per tahun.

Adapun jenjang pendidikan masyarakat Desa Bulak Baru dari tahun 19832000 dapat dilihat pada tabel sebagai berikut ini.

Tabel 2. Jenjang pendidikan penduduk Desa Bulak Baru tahun 1983-2000

\begin{tabular}{|l|l|l|l|l|l|}
\hline \multirow{2}{*}{ Tahun } & \multicolumn{3}{|l|}{ Jenjang Pendidikan } \\
\cline { 2 - 6 } & $\begin{array}{l}\text { Tidak } \\
\text { Sekolah }\end{array}$ & SD & SLTP & SLTA & $\begin{array}{l}\text { Perguruan } \\
\text { Tinggi }\end{array}$ \\
\hline $\mathbf{1 9 8 3 - 1 9 8 9}$ & 284 & 289 & 87 & 14 & - \\
\hline $\mathbf{1 9 9 0 - 1 9 9 6}$ & 216 & 321 & 143 & 56 & - \\
\hline $\mathbf{1 9 9 7 - 2 0 0 0}$ & 148 & 284 & 226 & 109 & 4 \\
\hline
\end{tabular}

Sumber: Rekap data kependudukan Desa Bulak Baru (tanpa tahun)

Dilihat dari data tabel di atas tampak bahwa setiap tahun kesadaran pendidikan semakin meningkat. Masyarakat yang tidak sekolah jumlahnya setiap tahun semakin sedikit, artinya terus terjadi penurunan. Hanya saja penurunan itu belum signifikan karena salah satu faktornya adalah para orang tua yang tidak berpendidikan masih relatif banyak. Periode tahun 1997-2000an merupakan periode terbaik dalam kesadaran masyarakat tentang pendidikan. Pada periode tersebut, terjadi peningkatan angka partisipasi pendidikan masyarakat Desa Bulak Baru pada jenjang sekolah dasar, sekolah menengah pertama, dan atas. Juga diikuti mulai adanya masyarakat yang sudah mengenyam perguruan tinggi walau jumlanya masih sedikit yaitu 4 orang. Pekerjaan masyarakat desa Bulak Baru tahun 1983-2000 sebagai berikut: 
Tabel 3. Pekerjaan masyarakat Desa Bulak Baru tahun 1983-2000

\begin{tabular}{|c|c|c|c|c|c|c|}
\hline \multirow{2}{*}{ Tahun } & \multicolumn{6}{|c|}{ Pekerjaan } \\
\hline & Nelayan & Petani & Buruh & Mebel & Pedagang & PNS \\
\hline 1983-1989 & 173 & 47 & 39 & 12 & 28 & - \\
\hline 1990-1996 & 126 & 54 & 46 & 36 & 25 & - \\
\hline 1997-2000 & 119 & 32 & 40 & 82 & 33 & 1 \\
\hline
\end{tabular}

Sumber: Rekap data kependudukan Desa Bulak Baru (tanpa tahun)

Dari setiap periode selalu terjadi penurunan jumlah masyarakat yang bekerja sebagai nelayan. Salah satu faktor utamanya adalah jarak desa yang semakin jauh dengan laut, sehingga banyak yang beralih profesi ke yang lainnya. Alih profesi itu melanda kalangan pemuda yakni ke bidang pekerjaan mebel. Pada tahun 1990-an, trend pekerjaan mebel di Jepara mengalami kemajuan berarti. Kemjauan itu ikut mendorong sebagian besar penduduk berusia muda bekerja di sektor pembuatan mebel. Mebel Jepara pemasarannya ke luar negeri. Pada periode 1997-2000, terdapat kemanjuan di mana masyarakat desa ikut menjadi Pegawai Negeri Sipil. Data itu menandakan bahwa ada peningkatan dan kemajuan pada penduduk Desa Bulak Baru yang sebelumnya belum pernah terjadi. Fakta itu juga memberi arti bahwa pendidikan warga setempat ikut memberi peran dalam kemajuan warga desa.

Kemajuan Desa Bulak Baru juga didukung oleh institusi pendidikan tinggi di Jawa Tengah. Pada 1982 mahasiswa Universitas Diponegoro (Undip) yang melakukan Kuliah Kerja Nyata (KKN) membangun sumur untuk kepentingan warga desa. Sumur itu untuk memenuhi kebutuhan air bersih bagi penduduk. Pada tahun yang sama, pemerintah Kabupaten Jepara membangun jalan utama yang menghubungkan desa dengan ibukota kecamatan (Suara Merdeka 23 Oktober 1982). Nama jalan ini dinamakan dengan jalan Bulak Baru. Selain jalan, infrastruktur pendidikan dan fasilitas sosial lainnya seperti Masjid dan Sekolah tingkat Dasar yang baru dibangun pada tahun 1983 (Abduh Somad, 03 Juni 2019). Pemerintahan Desa Bulak Baru tahun 1983-2000 tidak banyak mengalami perubahan, struktur pemerintahan desa masih sama dengan desa lainnya. Perubahan yang terjadi dalam sistem pemerintshan Desa Bulak Baru adalah Kepala desa tidak lagi dipilih langsung oleh rakyat melalui pemilu, namun melalui musyawarah para pejabat pemerintah desa yang kemudian diajukan dan diangkat oleh pemerintah kecamatan. Perubahan cara pemilihan dan penetapan menjadi kepala desa itu karena masyarakat Desa Bulak Baru tidak ada yang bersedia menjadi kepala desa. Masyarakat merasa bahwa menjadi pejabat/kepala desa tugas dan tanggung jawab yang diemban terlalu berat dan merepotkan. Padahal dalam kenyataannya, dalam menjalankan pemerintahan desa, kepala desa dibantu oleh Sekretaris Desa (carik), bendahara desa (kamituo), pamong desa (kebayan), dan pemimpin agama (modin). Tenaga penunjang juga selalu membantu pejabat desa dalammelayani masyarakat sehari-hari.

Bencana dan Bedol Desa

Desa Bulak secara geografis terletak di pesisir pantai Laut Jawa. Desa ini mempunyai hutan mangrove sebagai benteng alami penghambat gelombang air laut yang berada di pesisir pantai. Pusat desa dan pemukiman Bulak berlokasi di tanah berlumpur. Kondisi itu menyebabkan Desa Bulak rentan terhadap abrasi dan gelombang pasang. Tanaman mangrove menjadi satu-satunya benteng untuk 
menghambat gelombang air laut dan ancaman abrasi. Kondisi ekologi desa yang tanahnya berlumpur itu pada perkembangannya mengalami abrasi juga. Abrasi di Desa Bulak lebih disebabkan karena tidak kuatnya cengkraman akar pohon mangrove pada tanah. Cengkraman yang tidak kuat tersebut dan dengan tekanan gelombang yang datang terus menerus. Akibatnya adalah mengerus akar mangrove dari bawah sehingga pohon mangrove terseret oleh gelombang.

Menurut keterangan dari Masnur, warga desa Bulak, upaya yang dilakukan masyarakat Desa saat mengetahui pohon mangrove yang dirusak oleh gelombang adalah memungutnya dan mengikatnya pada pohon yang tidak tergerus ombak agar tidak roboh. Kondisi itu terus berlangsung dalam periode yang panjang, khususnya pada musim barat yang disertai angin kencang dan curah hujan tinggi. Dampak dari kondisi tersebut adalah terkikisnya tanaman manggrove dan semakin parahnya kondisi di bawah pohon manggrove karena terus abrasi oleh air hujan. Kondisi itu terus berlangsung berbulan-bulan dan masyarakat Bulak hanya bisa bertahan dalam kondisi yang tidak menentu. Jalan keluar pun terus dicari, namun tidak ada hasil yang memuaskan karena abrasi dan banjir rob terus mengancam warga desa. Abrasi dan rob yang besar dan menjadi bencana bagi warga desa terjadi pada tahun 1971 dan 1979.

Pada tahun 1971 abrasi yang dialami masyarakat Desa Bulak membawa penderitaan yang berarti karena disertai angin puting beliung. Angin puting beliung yang berhembus kencang menyebabkan gelombang besar dan membuat air laut naik ke daratan sekitar 30 meter. Akibat dari peristiwa tersebut, 40 rumah warga roboh dan terendam air laut. Warga desa juga ada yang meninggal dunia, yakni 1 jiwa. Penyebab warga meninggal adalah karena tertimpa bangunan rumah yang roboh (Wawancara dengan Masnur, 08 Juni 2019). Masyarakat yang terdampak bencana tersebut kemudian memutuskan untuk mengungsi ke rumah sanak saudaranya yang berada di desa sekitar seperti Desa Bugel, Desa Tanggul Tlare, Desa Teluk Awur, dan Desa Semat. Tidak semua masyarakat Desa Bulak pergi untuk mengungsi.

Mereka yang pergi mengungsi adalah anak-anak dan wanita. Para pengungsi itu berasal dari masyarakat yang tempat tinggalnya rusak karena angin putting beliung dan terendam air laut (rob). Untuk menyelesaikan permasalahan bagi masyarakat yang rumahnya rubuh dan terendam air, maka dilakukan musyawarah sebagai cara untuk menemukan dan menentukan jalan keluar. Musyawarah yang dilakukan masyarakat dengan pemerintah Desa Bulak. Hasil musyawarah tersebut sesuai kesepakatan maka masyarakat yang rumahnya roboh dan terendam air direlokasi secara swadaya. Tempat relokasi yang dipilih berjarak $1 \mathrm{~km}$ di sebelah timur desa yang letaknya sejajar dengan jalan Kedung-Jepara. Relokasi tersebut menempati tambak milik masyarakat dengan luas 1,5 ha. Penempatan warga desa di tambak sebagai tempat relokasi dilakukan dengan cara menimbun atau menguruk tambak dengan tanah. Bagi masyarakat yang tidak mempunyai lahan tambak di daerah tersebut memberi ganti rugi kepada masyarakat pemilik tambak yang lahannya digunakan sebagai tempat relokasi.

Selain direlokasi, ada juga masyarakat yang terdampak diberi solusi untuk mengikuti program transmigrasi dari pemerintah. Mayoritas masyarakat yang ikut transmigrasi dikirim ke daerah Lampung. Pada perkembangannya, masyarakat Desa Bulak terus mengalami ancaman rob. Ancaman nyata benar-benar terjadi pada tahun 1979 ketika bencana rob dan angin yang melanda Desa Bulak. Pada Desember 1979, 
pukul 03.00 dini hari waktu setempat hujan badai disertai ombak besar mengakibatkan naiknya air laut ke daratan menyebabkan abrasi lagi pada Desa Bulak.

Menurut penuturan dari Abduh Somad, saksi hidup yang mengalami langsung ketika bencana tersebut terjadi. Somad menggambarkan bahwa bencana yang terjadi pada saat itu seperti tsunami kecil yang melanda Desa Bulak. Air laut yang naik ke daratan ketinggiannya mencapai sepinggang orang dewasa. Ombak besar menerjang dan merendam rumah penduduk beserta jalan desa. Angin yang bertiup sangat kencang membuat keadaan semakin parah. Semua masyarakat Desa Bulak saat itu dalam keadaan panik, namun karena mereka sudah pernah mengalaminya, maka kepanikan warga desa tidak seperti sebelumnya. Meskipun demikian bencana pada periode ini adalah bencana terbesar dengan rincian 57 rumah penduduk rusak dan sebagian besar wilayah desa terendam oleh air oleh rob.

Walaupun bencana yang datang lebih parah dari bencana yang pertama, tetapi bencana pada tahun ini tidak ada korban jiwa. Sebagian besar masyarakat yang berjumlah sekitar $100 \mathrm{KK}$ (Kepala Keluarga) kemudian mengungsi ke luar desa menuju rumah sanak saudara yang terdekat antara lain: ke Desa Bugel, Desa Tanggul Tlare, Desa Semat dan Desa Teluk Awur. Beberapa warga desa memutuskan untuk tetap bertahan di Desa Bulak. Masyarakat yang bertahan pada umumnya adalah para laki-laki dan rumahnya dalam kondisi tidak parah. Jangka waktu pengungsian warga pada bencana ini memakan waktu lebih lama, yakni 1 tahun. Kondisi yang demikian itu mendorong masyarakat desa melakukan bedol desa pada tahun 1982. Persiapan untuk melakukan perpindahan warga desa itu telah dilakukan sejak tahun 1981.

Pada April tahun 1981 setelah mendapat laporan dari Bupati Jepara, Hisom Prasetyo tentang keadaan yang dialami oleh masyarakat Desa Bulak. Gubernur Jawa Tengah Soepardjo Rustam kemudian melakukan peninjauan pada lokasi terjadinya bencana. Hasil dari peninjauan tersebut Gubernur, mengusulkan untuk dilakukan pemindahan terhadap masyarakat Desa Bulak. Hal itu didasari oleh bencana yang telah dan terus melanda Desa Bulak dan air laut yang terus naik ketika air pasang. Kondisi itu mengakibatkan Desa Bulak tidak bisa ditempati lagi karena dikhawatiran terhadap bencana yang lebih parah kembali melanda desa.

Pada Mei tahun 1981, Pemerintah Kabupaten Jepara menawarkan kepada masyarakat Desa Bulak untuk ikut dalam program transmigrasi. Penawaran diberikan dengan pertimbangan bahwa: (1) Banyak rumah masyarakat yang rusak dan desa yang semakin dekat dengan laut. (2) Mensukseskan program transmigrasi oleh pemerintah untuk pemerataan penduduk di Indonesia. Tawaran transmigrasi yang diberikan oleh Pemerintah Kabupaten Jepara tersebut ditolak oleh masyarakat dengan alasan: (1) Masyarakat takut tidak bisa menyesuaikan diri dengan daerah yang dituju karena keadaan alam yang berbeda dari daerah asal. (2) Jauh dari sanak keluarganya yang berada di Jawa.

Menyikapi penolakan dari masyarakat kemudian pemerintah Desa Bulak mencoba melakukan musyawarah dengan pemerintah Kabupaten Jepara untuk menemukan solusinya. Musyawarah tersebut menghasilkan kesepakatan bahwa masyarakat akan direlokasi ke arah timur sejauh $3 \mathrm{Km}$ tepatnya di sebagian daerah persawahan desa Bugel karena: (1) Daerahnya cukup luas dan keadaan alamnya sama dengan wilayah desa Bulak. (2) Banyak leluhur masyarakat desa Bulak berasal 
dari desa Bugel. (3) Harga lahan murah yaitu Rp. 100/ $\mathrm{M}^{2}$ karena lahan sawah tandus. Luas lahan yang dibeli pemerintah sekitar 3 Ha (Wawancara dengan Abduh Somad, 03 Juni 2019).

Relokasi yang dilakukan tersebut menggunakan model pola pemukiman terpusat yaitu pola pemukiman yang terkonsentrasi pada satu lokasi (Saebani, 2015: 36). Pada awalnya pemerintah menawarkan dua tipe pola pemukiman yaitu, (1) pola memanjang sepanjang jalan Bugel-Bulak, dan (2) Pola pemukiman terpusat. Pola pemukiman terpusat dipilih karena masyarakat merasa khawatir dengan keamanan desa yang pada saat itu rawan kejahatan. Dengan pola pemukiman terpusat memudahkan masyarakat untuk bertindak saling menolong jika terjadi suatu hal. Pemukiman tersebut terletak di bagian timur laut desa dengan berbentuk tanah kavling. Masing-masing ukuran kavling seluas $10 \mathrm{M}$ x $15 \mathrm{M}$ yang dibagikan setiap keluarga. Pembagian tanah kavling tersebut dilakukan dengan cara diundi agar adil.

Proses perpindahan masyarakat Desa Bulak tidak selalu berjalan lancar. Karena masih banyak masyarakat Desa Bulak yang belum mau pindah ke daerah tersebut dikarenakan mereka menggap daerah relokasi tersebut selain rawan kejahatan juga merupakan daerah yang dianggap angker (wingit). Namun akhirnya proses perpindahan diawali oleh para pejabat pemerintah Desa Bulak untuk membuktikan bahwa daerah tersebut sudah aman. Lambat laun banyak, akhirnya masyarakat yang awalnya masih belum mau pindah kemudian sudah bersedia pindah ke lokasi desa yang baru. Warga yang pindah mendapatkan bantuan pemerintah berupa lahan dan material bangunan untuk kebutuhan pendirian rumah di lokasi baru.

Relokasi pemindahan masyarakat dilakukan secara bertahap dimulai pada bulan Oktober tahun 1981 dan berakhir pada Oktober 1982. Pada Juli 1982 hanya 75 KK yang baru pindah dari total keseluruhan jumlah 140 KK. Sejumlah 65 KK yang belum pindah karena lahan yang masih kurang dan menunggu penambahan area lahan dari pemerintah. Menyikapi hal tersebut kepala desa kemudian mengusulkan penambahan kekurangan lahan sekitar 0,75 hektar dan bantuan pembangunan masjid kepada pemerintah kabupaten melalui Camat Kedung. Usulan penambahan lahan seluas 0,75 hektar tersebut meliputi 0,5 hektar lahan digunakan sebagai pemukiman masyarakat dan 0,25 hektar untuk lahan untuk Sekolah Dasar.

Pada Oktober tahun 1982 dilakukan penambahan lahan sekitar 1 (satu) ha untuk menampung masyarakat yang belum pindah dan pembangunan Sekolah Dasar Inpres dan masjid. Walaupun masyarakat berpindah dan mendirikan desa di wilayah baru. Masyarakat masih tetap mempertahankan identitasnya sebagai masyarakat Desa Bulak. Lokasi relokasi yang dipilih adalah lokasi yang jaraknya tidak jauh dan keadaan geografisnya hampir sama dengan Desa Bulak. Secara kultural mereka juga masih menegaskan bahwa mereka berasal dari Desa Bulak. Penegasan tersebut dapat dilihat dari nama desa baru yang mereka tempati dengan nama Desa Bulak Baru.

\section{Kehidupan Masyarakat di Desa Bulak Baru 1983-2000}

Kehidupan masyarakat sebelum dan sesudah relokasi berbeda. Perbedaan tersebut nampak pada kehidupan sosial ekonomi masyarakat beserta perubahan sarana prasarana desa yang tersedia. Selain itu, paska relokasi masyarakat masih 
mendapat bantuan dari pemerintah kabupaten dan pendampingan oleh mahasiswa KKN dari Universitas Diponegoro (UNDIP). Pada pertengahan tahun 1983 pemerintah kabupaten melalui Bupati Jepara Hisyom Prasteyo memberi bantuan uang sebesar Rp. 100.000,- kepada masyarakat Desa Bulak Baru untuk pembangunan masjid desa. Pemberian bantuan diberikan pada bulan Oktober tahun 1983 ketika Bupati Jepara mengadakan kunjungan ke Desa Bulak Baru. Pembangunan sarana umum berupa jalan utama penghubung antara Desa Bulak Baru dengan ibukota kecamatan sejauh 3 km juga dilakukan. Melalui proyek Padat Karya Gaya Baru jalan utama penghubung Desa Bulak Baru dengan ibukota kecamatan yang semula hanya jalan setapak melewati areal persawahan ditinggikan dan dikeraskan. Sehingga ketika musim penghujan jalan tersebut tidak lagi terendam bajir (Suara Merdeka, 23 Oktober 1982).

Sarana umum lain yang ikut dibangun adalah fasilitas pendidikan Sekolah Dasar. Ketika masih berada di Desa Bulak tidak tersedia fasilitas pendidikan dan setelah masyarakat direlokasi ke Desa Bulak Baru mulai dibangun fasilitas pendidikan berupa Sekolah Dasar (SD) pada tahun 1983. Pembangunan tersebut bertujuan sebagai penunjang kegiatan pendidikan masyarakat desa Bulak Baru yang sebelumnya tidak mempunyai fasilitas pendidikan khususnya pendidikan dasar sehingga masyarakat tidak harus keluar desa untuk bersekolah (Wawancara dengan Masnur, 06 Juli 2019). Bantuan sarana hiburan juga diberikan Bupati Jepra Hisyom Prasetyo kepada masyarakat Desa Bulak Baru berupa sebuah pesawat televisi yang pada saat itu masih jarang dimiliki dan menjadi sebuah barang yang istimewa.

Sesuai harapan Bupati Jepara Hisyom Prasetyo kepada masyarakat Desa Bulak Baru agar melakukan penghijauan lingkungan disekitar pemukiman. Mahasiswa UNDIP yang saat itu sedang KKN di Desa Bulak Baru meresponnya dengan cara melakukan pendampingan penghijauan lingkungan kepada masyarakat. Pendampingan yang dilakukan oleh mahasiswa KKN UNDIP pada tahun 1983 berupa pelatihan penanaman bibit pohon. Dikarenakan kondisi tanah desa yang sulit ditanami karena bekas sawah tandus, masyarakat dilatih dengan cara menanam bibit pohon di dalam kantong plastik yang di dalamnya di isi dengan tanah yang subur. Pemerintah desa mewajibkan minimal setiap rumah wajib menanam dua pohon di halaman dengan jenis pohon yang berbuah, seperti: pohon mangga dan jambu agar dapat diambil buahnya di kemudian hari. Tujuan dari penghijauan lingkungan tersebut agar lingkungan Desa Bulak Baru tidak terlihat gersang. Bentuk pengabdian lain yang dilakukan mahasiswa KKN UNDIP kepada masyarakat Desa Bulak Baru adalah pembangunan sumur desa. Sehingga bisa dimanfaatkan oleh masyarakat untuk memenuhi kebutuhan sehari-hari seperti memasak dan mandi.

Perubahan yang terjadi setelah relokasi ke Desa Bulak Baru dalam bidang sosial yang lain berupa perubahan tempat tinggal. Sedangkan dalam bidang ekonomi berupa perubahan dalam mata pencaharian. Tempat tinggal masyarakat ketika belum direlokasi ke Desa Bulak Baru bisa dikatakan hanya sedikit yang berupa bangunan tembok permanen. Tetapi setelah masyarakat di relokasi ke Desa Bulak Baru seluruh bangunan tempat tinggal masyarakat berupa bangunan tembok permanen. Hal itu tidak terlepas dari peran pemerintah dalam memberi bantuan berupa bahan material bangunan kepada masyarakat. Pemukiman masyarakat juga terlihat lebih rapi dibandingkan sebelum relokasi karena setiap jarak dua bangunan 
rumah diberi gang.

Jarak desa yang semakin jauh dengan laut mengakibatkan berkurangnya masyarakat yang bekerja sebagai nelayan. Pada umumnya beralih pekerjaan sebagai tukang kayu (mebel) dan petani. Masyarakat yang bekerja sebagai tukang kayu atau mebel kebanyakan adalah anak muda yang bekerja ke luar daerah. Setelah dirasa cukup mendapatkan uang untuk modal usaha kemudian mereka membuka mebel sendiri di rumah. Bagi masyarakat yang beralih mata pencaharian menjadi petani dan tidak mempunyai sawah sendiri mereka bekerja sebagai buruh tani atau menyewa lahan pertanian. Peralihan mata pencaharian menjadi petani lebih disebabkan karena jarak desa yang lebih dekat ke area persawahan.

Meskipun masyarakat mengalami perubahan dalam bidang sosial ekonomi dan sarana prasarana tetapi tidak dalam bidang pemerintahan. Dalam bidang pemerintah desa, para pejabat desa adalah pejabat yang sudah menjabat sebelum bedol desa. Kepala Desa Sutoyo menjabat sampai tahun 1998, setelah ini tidak ada pemilihan kepala desa karena Desa Bulak Baru dianggap desa kecil yang terdiri hanya 1 RW sehingga terjadi kekosongan jabatan kepala desa. Sebagai pejabat sementara adalah Zaenal Abidin (petugas kecamatan) sampai tahun 2001. Jabatan sekretaris desa (carik) dijabat oleh Masnur sampai tahun 2016. Posisi modin dijabat oleh Abdul Hamid sampai tahun 1985 dan kemudian digantikan oleh Ismail sampai tahun 2011. Jabatan pamong desa (bayan) dijabat oleh dua orang yaitu Suprat dan Masduki. Tahun 1985 terjadi kekosongan jabatan karena Supat pensiun dan posisi bayan hanya dijabat oleh Masduki sampai tahun 2000. Bendahara desa dijabat Subardi sampai tahun 2011. Bagian pengairan (ladu) dijabat Sarmin sampai tahun 2011. Jabatan kamituwo dijabat Fathoni sampai tahun 1996 dan sempat terjadi kekosongan jabatan sebelum akhirnya pada tahun 2000 dijabat oleh Gesan.

\section{KESIMPULAN}

Desa Bulak mengalami transformasi di level lokal karena satu hal, yakni bencana alam yang rutin melanda masyarakat Bulak. Akibat dari bencana itu memaksa warga melakukan perpindahan lokasi pemukiman, yakni ke Desa Bulak Baru. Penamaan desa diambil dari nama awalnya dan menambahkannya dengan identitas "baru" karena lokasi desa di tempat/lokasi baru. Desa Bulak Baru menjadi identitas baru dari desa sebelumnya dalam arti, bukan merupakan nama desa yang dipisah, tetapi nama desa lama yang semua warga Desa Bulak Baru adalah warga Desa Bulak.

Dalam rentang periode penelitian, terjadi beberapa perubahan yakni pada perkembangan demografi, pendidikan, dan fasilitas sosial serta infrastruktur jalan. Selain itu, tingkat kesejahteraan penduduk juga meningkat yang ditandai dengan meningkatnya level pendidikan warga desa dan beberapa warga desa bekerja sebagai aparatur sipil negara (ASN). Keterlibatan pemeritah dan lembaga pendidikan tinggi seperti Universitas Diponegoro dan pemerintah Propinsi dan Kabupaten telah mempercepat perubahan sosial masyarakat Desa Bulak Baru. 


\section{DAFTAR PUSTAKA}

\section{Harian}

"Desa Bulak Jepara Terancam Erosi Gelombang Laut; 75 KK Pindah", dalam Suara Merdeka, 1 Juli 1982 p. 4.

“Di Daerah Jepara: Desa Bulak Ganti Nama, Semua Penduduk Pindah Karena Erosi", dalam Suara Merdeka Oktober 1982, p. 4.

\section{Wawancara}

Masnur. (2019, Juni 8). Wawancara (2019. Juli 6). Wawancara

Somad, A. (2019. Juni 3). Wawancara

Sunadi. (2019. Juli 12). Wawancara

\section{Buku}

Herabudin. (2015). Pengantar Sosiologi. Pustaka Setia.

Hidayani, Noviarti. (2016). “Dinamika Sosial Kehidupan Transmigrasi di Nagari Kamang Kabupaten Sijunjung (1993-2014)". Skripsi. Padang: Universitas Andalas.

Rahardjo. (2014). Pengantar Sosiologi Pedesaan dan Pertanian. Gadjah Mada University Press.

Rekap data kependudukan Desa Bulak Baru Tahun 1993-2000 (tanpa tahun).

Saebani, Beni A. (2015). Sosiologi Perdesaan. Pustaka Setia.

Soekanto, Soerjono. (1982). Sosiologi: Suatu Pengantar. CV Rajawali.

Syafruddin, A., \& Suprin, N. (2010). Republik Desa: Pergulatan Hukum Tradisional dan Hukum Modern dalam Desain Otonomi Desa. PT. Alumni.

Tim Penyusun Kamus Pusat Pembinaan dan Pengembangan Bahasa. (2008). Kamus Besar Bahasa Indonesia. Gramedia Pustaka Utama. 